\title{
Seasonal Changes in Microbial Density and Diversity of Ikpoba River Water Samples in Benin City Nigeria
}

\author{
Akpe Azuka Romanus ${ }^{1,}$, , Okwu Grace Ifeoma ${ }^{1}$, Umanu Goddey ${ }^{2}$, Femi Imah Justus ${ }^{2}$ \\ ${ }^{1}$ Department of Microbiology, Ambrose Alli University, Ekpoma, Nigeria \\ ${ }^{2}$ Department of Biological Sciences, Bells University of Technology, Ota, Nigeria
}

Email address:

lordromis@yahoo.co.uk (A. A. Romanus)

${ }^{*}$ Corresponding author

\section{To cite this article:}

Akpe Azuka Romanus, Okwu Grace Ifeoma, Umanu Goddey, Femi Imah Justus. Seasonal Changes in Microbial Density and Diversity of Ikpoba River Water Samples in Benin City Nigeria. International Journal of Microbiology and Biotechnology. Vol. 3, No. 2, 2018, pp. 36-43. doi: $10.11648 /$ j.ijmb.20180302.12

Received: March 25, 2018; Accepted: April 11, 2018; Published: May 17, 2018

\begin{abstract}
River water is a major source of water for household use in most rural communities in Nigeria. River pollution refers to the contaminations of rivers which occur when waste and different other pollutants are discharged into river without being properly treated. Studies on river water pollution and their implication to public health has been ongoing. An assessment of the seasonal changes in microbial density and diversity of Ikpoba River in Benin City, Nigeria was carried out between the months of January to March and May to July 2017 for the dry and wet seasons. Standard microbiological procedures were used for the study. Results showed that the density of the microbial isolates was highest during the dry season. There is significant difference $(\mathrm{P}>0.05)$ in the heterotrophic microbial counts in both seasons. The discharge point, upstream and downstream bacterial counts for dry season ranged from $1.5 \pm 0.00 \times 10^{4} \mathrm{cfu} / \mathrm{ml}$ to $4.0 \pm 0.23 \times 10^{6} \mathrm{cfu} / \mathrm{ml}$ whereas the wet season samples had lower counts ranging from $2.0 \pm 0.05 \times 10^{3} \mathrm{cfu} / \mathrm{ml}$ to $4.0 \pm 0.21 \times 10^{4} \mathrm{cfu} / \mathrm{ml}$. Similarly, the fungi counts for the dry season ranged from $6.0 \pm 0.01 \times 10^{2} \mathrm{cfu} / \mathrm{ml}$ to $1.4 \pm 0.53 \times 10^{6} \mathrm{cfu} / \mathrm{ml}$ while for the wet season it ranged from $5.0 \pm 0.00 \times 10^{2} \mathrm{cfu} / \mathrm{ml}$ to $9.0 \pm 0.32 \times$ $10^{4} \mathrm{cfu} / \mathrm{ml}$. The highest counts were at the point of discharge while the lowest counts were recorded for the upstream samples. The diversity of the microbial species was more in the wet season than in the dry season. The bacteria isolated during the dry season were Salmonella sp, E. coli, and Vibrio sp. In the wet season the isolates included E. coli, Salmonella sp, Vibrio sp, Staphylococcus aureus, and Streptococcus faecalis. The wet season fungi isolates were Aspergillus fumigatus, Aspergillus niger, species of Penicillium and Rhizopus while the dry season isolates included Aspergillus fumigatus, Aspergillus niger and species of Penicillium. The microbial density is higher in the dry season and lower in the wet season while there are more microbial diversities in the wet season than in the dry season.
\end{abstract}

Keywords: Microbial Density and Diversity, Coliforms, River Water, Pollution

\section{Introduction}

There are various forms of industrial wastes that interfere with the quality of life of all living creatures and with the earth's ecological system. Some of these industrial wastes if allowed into the environment cause environmental pollution [1].

Water pollution is a problem globally, involving the discharge of dissolved or suspended substances into groundwater, streams, rivers and oceans [2]. Surface waters are usually exposed to contamination from point sources such as pollution from oil spillage and non-point sources from agricultural runoff. Some of the pollution enriches the water body with nutrients leading to growth of algae and other phyto-plankton which shade or clog the water surface, making it anoxic. When this pollution reaches the highest level, the oxygen concentration of the bottom of the stream become zero, a zone of putrefaction will occur with the production of hydrogen sulphide $\left(\mathrm{H}_{2} \mathrm{~S}\right)$, ammonia $\left(\mathrm{NH}_{3}\right)$ and other odorous gases leading to the death of many fish species and other aquatic organisms [3].

Wastewater from industry may include sanitary waste of employees, processing waste from the manufacturing industries, water emanating from washing factory floor as well as those utilized in various cooling systems [4].

Brewery waste or effluent is the resulting liquid from a 
waste water treatment system of a brewery factory. The quality and quantity of brewery waste fluctuates depending on the processing that takes place within the period and the nature of the waste generated [5]. Industrial waste if present in water causes a change in physical, biological, and radiological quality of water making it injurious to its uses.

Study has shown that the quality and the kind of waste produced by a factory depend largely on the frequency of production and the kind of production involved during the period [6]. When these waters are not effectively treated before discharge, they pollute the receiving streams. The effect of untreated waste on receiving streams is poisoning of drinking water, damage to habitats of marine animals and it neutralizes irrigation system of agriculture. This further result in shortage of potable water, death of aquatic animals, alteration of the colour of water body and outbreak of waterborne diseases [7].

Pollution affects the biosphere plants and the organisms living in these water bodies including human health. Researchers have confirmed the negative effect of industrial effluents discharge on rivers [8-12]. There is therefore the need to control the pollution of surface and groundwater since the health and well-being of the people is directly dependent on the availability of good water. The Ikpoba River in Benin-city, Edo State receives effluents from Guinness Plc (a brewery industry). Other sources of pollution of Ikpoba River include waste from abattoir, faecal matter from people living within the vicinity, pollution from laundry activity such as washing and bathing, and other nonpoint sources. Some of these industries dump their waste directly on rivers, lakes, seas, oceans etc resulting in water pollution. Surface water are usually exposed to microbial contamination from runoffs and any waste deliberately or inadvertently dumped into such waters. These can result to pollution, increase in microbial load, eutrophication, reduction in aesthetic value and loss of recreational activities [13].

The quality of waste discharge from industry depends on the activities of the industry in terms of production. Breweries for example are known to consume water of about 4 to 8 cubic meter of beer produced [2]. Brewery plant has been known to cause pollution by discharging effluent into receiving streams, groundwater and soil [10].

Ikpoba River is a fourth order stream located in Benin-city, Edo state in south western Nigeria. It is one of such rivers that receive domestic and agricultural waste from Oregbeni and other communities living at its banks and abattoir. Also, fishing, bathing, washing, and swimming take place in the river. All these introduce foreign microorganisms, organic and inorganic matter in addition to indigenous micro flora. The Oregbeni community flanks the river on one side behind Guinness Nigeria Plc and Bendel Brewery Ltd.

Related studies on this research which dealt on the effects of brewery effluents on the microbiological quality of Ikpoba River and the surrounding borehole water in Benin-City and the influence of brewery effluent discharge on the microbiological and physicochemical quality of Ikpoba River, Benin-city has been reported $[8,14,15]$. In addition to many articles already published, there is need to carry out a seasonal variations study to identify the effects of season on the microbiological quality of Ikpoba River.

\section{Methods}

\subsection{Sample Collection}

Water samples were collected from Ikpoba River at three different sampling points. The sampling points were designated upstream (US), Downstream (DS), and Discharge point (DP). The three sampling points were $100 \mathrm{~m}$ distant from each other. Three samples were collected into a $500 \mathrm{ml}$ clean sterile screw cap container from each sampling point making a total of nine (9) samples at each time of sampling and this was done fortnightly for 10 times for the two seasons. The samples were collected by immersing the sample container $30 \mathrm{~cm}$ deep into the river towards the current.

Dry season samples were collected from January to March and wet season samples were obtained from May to July 2017

\subsection{Microbiological Analysis}

\subsubsection{Bacterial Enumeration}

The total heterotrophic bacterial counts of the samples were determined by making ten-fold serial dilution of the samples on normal saline $(0.85 \% \mathrm{w} / \mathrm{v})$ sterile $\mathrm{NaCl}$. Then $1 \mathrm{~mL}$ of the appropriate dilution was pour plated in duplicates on the surface of MacConkey agar, nutrient agar, Salmonella Shigella agar and potato dextrose agar (supplemented with chloramphenicol to inhibit bacterial growth). The plates were then incubated for 24$48 \mathrm{~h}$ at a temperature of $37^{\circ} \mathrm{C}$ for bacteria. The fungi plates were incubated at $25^{\circ} \mathrm{C}$ to $30^{\circ} \mathrm{C}$ for $5-7$ days. Thereafter emerging colonies were counted. The coliform counts were determined using the multiple tube technique (involving three (3) principal tests - presumptive test, confirmed test and the completed test) as earlier described [16].

\subsubsection{Characterisation and Identification of Bacterial and Fungal Isolates}

The phenotypic and biochemical characteristics used to characterize and identify bacterial isolates included Gram staining, colonial appearance, motility, urease, catalase, indole, oxidase, citrate, methyl red, voges proskaeur and sugar fermentation. These tests were performed and emerging colonies identified using standard methods [17]. The fungal isolates were identified using cultural and morphological features [18].

\subsection{Statistical Analysis}

Data were analysed using analysis of variance (ANOVA) while significant means were separated with the Duncan's multiple range test using SPSS 17.0 statistics.

\section{Results and Discussions}

The results of the study on the microbial density and diversity of Ikpoba River is shown in tables 1-4 and figures 
1-3. The bacterial isolates in the two seasons included, Escherichia coli, Salmonella sp, Vibrio sp, Streptococcus faecalis and Staphylococcus aureus. Escherichia coli was the most predominant bacterial isolate followed by Salmonella sp. The fungal isolates were: Aspergillus niger, Aspergillus fumigatus, Penicillium spp and Rhizopus spp. Penicillium spp occurred most predominantly followed by Aspergillus spp.
The isolates and their various sources are shown in Table 1. The seasonal distribution of isolates is shown in table 2 with the wet season having more isolates. Table 3 showed the biochemical characteristics of bacteria isolated from the water samples. The cultural and morphological characteristics of fungal isolates are shown in table 4.

Table 1. Biochemical Characteristics of Bacteria Isolated from Ikpoba River.

\begin{tabular}{lllllll}
\hline Species & Gram & Motility & Catalase & Coagulase & Oxidase & Urea se \\
\hline E. coli & - & + & - & - & - & - \\
Salmonella sp & - & + & - & - & - & - \\
Streptococcus faecalis & + & - & - & - & - & - \\
Vibrio sp & - & + & - & - & - & - \\
Staphylococcus aureus & + & - & + & + & - & - \\
\hline
\end{tabular}

Table 1. Continued.

\begin{tabular}{|c|c|c|c|c|c|c|c|}
\hline Species & Citrate & VP & Glucose & lactose & Mannitol & Sucrose & $\mathrm{H}_{2} \mathrm{~S}$ \\
\hline E. coli & - & - & + & + & + & + & - \\
\hline Salmonella $\mathrm{sp}$ & + & - & + & - & + & - & + \\
\hline Streptococcus faecalis & + & + & + & + & + & + & - \\
\hline Vibrio $\mathrm{sp}$ & + & + & + & - & + & + & - \\
\hline Staphylococcus aureus & - & - & + & + & + & + & - \\
\hline
\end{tabular}

Key

$+=$ Positive Reaction

- =Negative Reaction

Table 2. Cultural and Morphological Characteristics of Fungi Isolated from Ikpoba River.

\begin{tabular}{ll}
\hline Appearances on Plates & Morphology \\
\hline $\begin{array}{l}\text { Grey fluffy mycelium } \\
\begin{array}{l}\text { Downy and powdery colony. White/black to deep } \\
\text { brown colony }\end{array}\end{array}$ & $\begin{array}{l}\text { Conidiophores arising from the mycelium singly or less. Conidia } \\
\text { hyaline or brightly coloured in mass, 1 celled, globose or ovoid } \\
\text { Septate/hyaline hyphae. Radiate conidial heads at earlier state, hyaline } \\
\text { conidiophores, globose vesicle, globose conidia with brown to black } \\
\text { colour which roughens with maturity }\end{array}$ \\
$\begin{array}{l}\text { Velvety colony. Downy and powdery colony with } \\
\text { shades of green and narrow border granular to cottony } \\
\text { colony. Colony white at first, then darkening to green } \\
\text { with white apron at the margin at later time }\end{array}$ & $\begin{array}{l}\text { Septate hyphae, smooth long conidiophores. Conidia arise in chains } \\
\text { and tend to sweep towards the central axis, have club-shaped vesicles }\end{array}$ \\
$\begin{array}{l}\text { Cotton-candy like colony, white colour at initial stage } \\
\text { which later turns grey to yellowish at later time }\end{array}$ & $\begin{array}{l}\text { Non-septate or sparsely septate. Broad hyphae, brown, unbranched } \\
\text { sporangiohores are visualized, hyaline to brown in colour, round with } \\
\text { flattened base. They can be solitary or form clusters }\end{array}$ \\
\hline
\end{tabular}

Table 3. Bacterial and Fungal Isolates from Ikpoba River Water Samples.

\begin{tabular}{llll}
\hline Sources of Isolates & & & Discharge Point \\
\hline Organism & Upstream & Downstream & + \\
\hline Escherichia coli & + & + & + \\
Salmonella sp & + & + & + \\
Staphylococcus aureus & + & + & + \\
Streptococcus faecalis & - & + & + \\
Vibrio sp & - & + & + \\
Aspergillus fumigatus & + & + & + \\
Aspergillus niger & + & + & + \\
Penicillium spp & + & + & + \\
Rhizopus spp & - & - & \\
\hline
\end{tabular}

Key

$+=$ Present

- = Absent 
Table 4. Seasonal Distribution of Isolates.

\begin{tabular}{lll}
\hline Organism & Dry season & Wet season \\
\hline Escherichia coli & + & + \\
Salmonella sp & + & + \\
Staphylococcus aureus & - & + \\
Streptococcus faecalis & - & + \\
Vibrio sp & + & + \\
Aspergillus fumigatus & + & + \\
Aspergillus niger & + & + \\
Penicillium spp & + & + \\
Rhizopus spp & - & + \\
\hline
\end{tabular}

Key

$+=$ Present

- = Absent

Figure 1 showed the dry and wet seasons heterotrophic bacterial count. The highest count $\left(580.00 \pm 20.00 \times 10^{2} \mathrm{cfu} / \mathrm{ml}\right)$ was recorded on Day 1 at discharge point (DP) while the lowest count $\left(1.67 \pm 0.12 \times 10^{2} \mathrm{cfu} / \mathrm{ml}\right)$ was recorded at upstream (US) on Day 28 both in the dry season. The highest count $\left(60.00 \pm 1.00 \times 10^{2} \mathrm{cfu} / \mathrm{ml}\right)$ in wet season analysis was recorded on Day 1 at DP while the lowest count $\left(1.80 \pm 0.20 \times 10^{2} \mathrm{cfu} / \mathrm{ml}\right)$ was recorded at US on Day 56. Figure 2 showed the dry and wet seasons heterotrophic fungal count of Ikpoba River water samples. The highest count $\left(110.00 \pm 10.0 \times 10^{2} \mathrm{cfu} / \mathrm{ml}\right)$ occurred on Day 1 at DP while the lowest count $\left(1.30 \pm 0.10 \times 10^{2} \mathrm{cfu} / \mathrm{ml}\right)$ was recorded on Day 28 at US in the dry season analysis. The highest count $\left(79.67 \pm 1.53 \times 10^{2} \mathrm{cfu} / \mathrm{ml}\right)$ in wet season was recorded at DP on Day 1 while the lowest count $\left(1.23 \pm 0.15 \times 10^{2} \mathrm{cfu} / \mathrm{ml}\right)$ was recorded at US on Day 42. Dry and wet seasons' most probable number of coliforms are shown in figure 3 . The highest count in dry season analysis was $47.00 \pm 3.00 / 100 \mathrm{ml}$ of water sample on Day 1 and 14 at DP while the lowest count $(8.00 \pm 1.00 / 100 \mathrm{ml})$ was recorded on Day 1 at US. The wet season analysis had the highest count $(39.00 \pm 3.00 / 100 \mathrm{ml})$ on Day 28 at DP. The lowest count $(2.00 \pm 0.00 / 100 \mathrm{ml})$ was recorded at US on Day 1 and 28 respectively and Day 1 at DP.
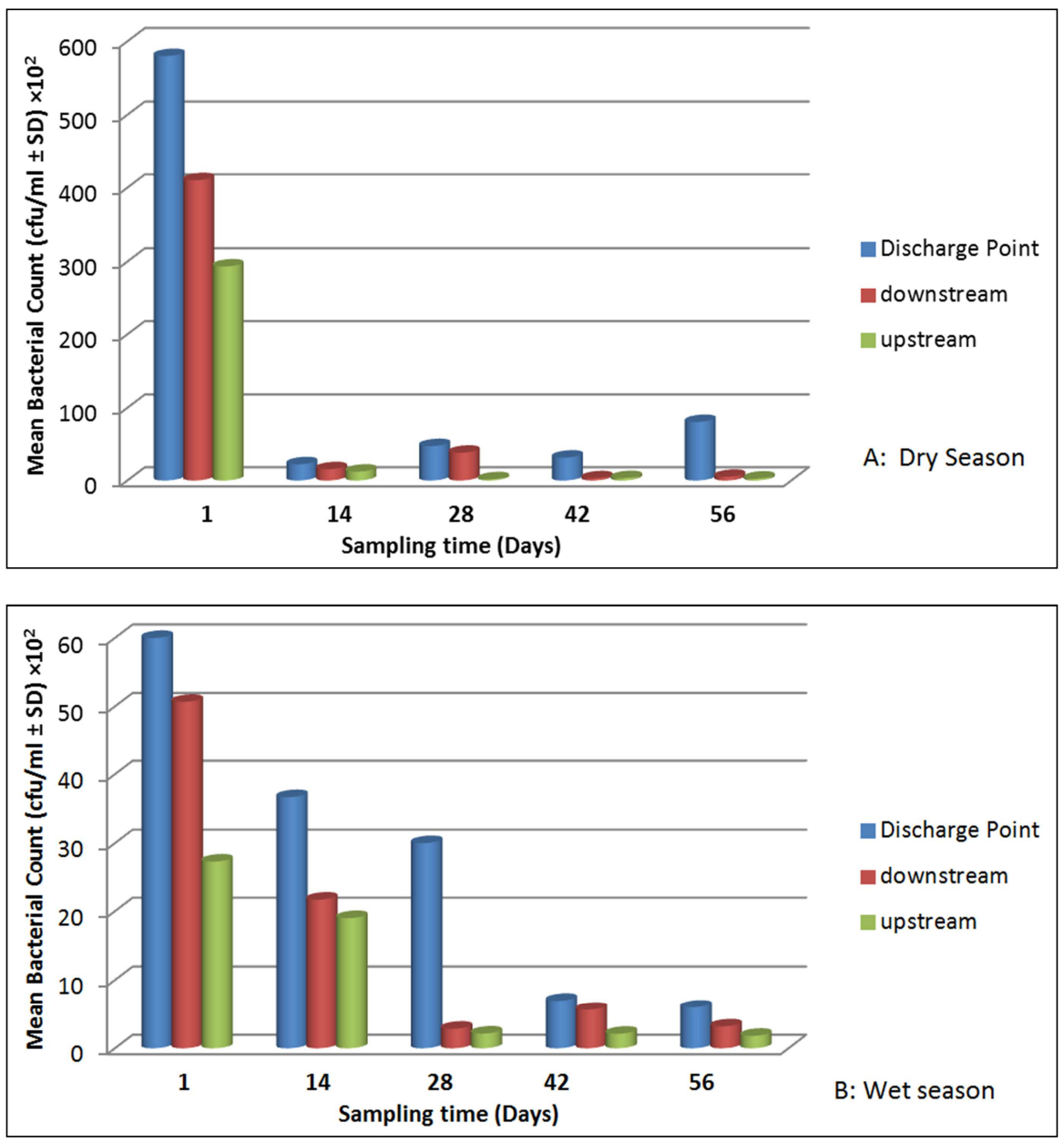

Figures 1. A and B Dry and Wet Seasons Heterotrophic Bacterial Count. 

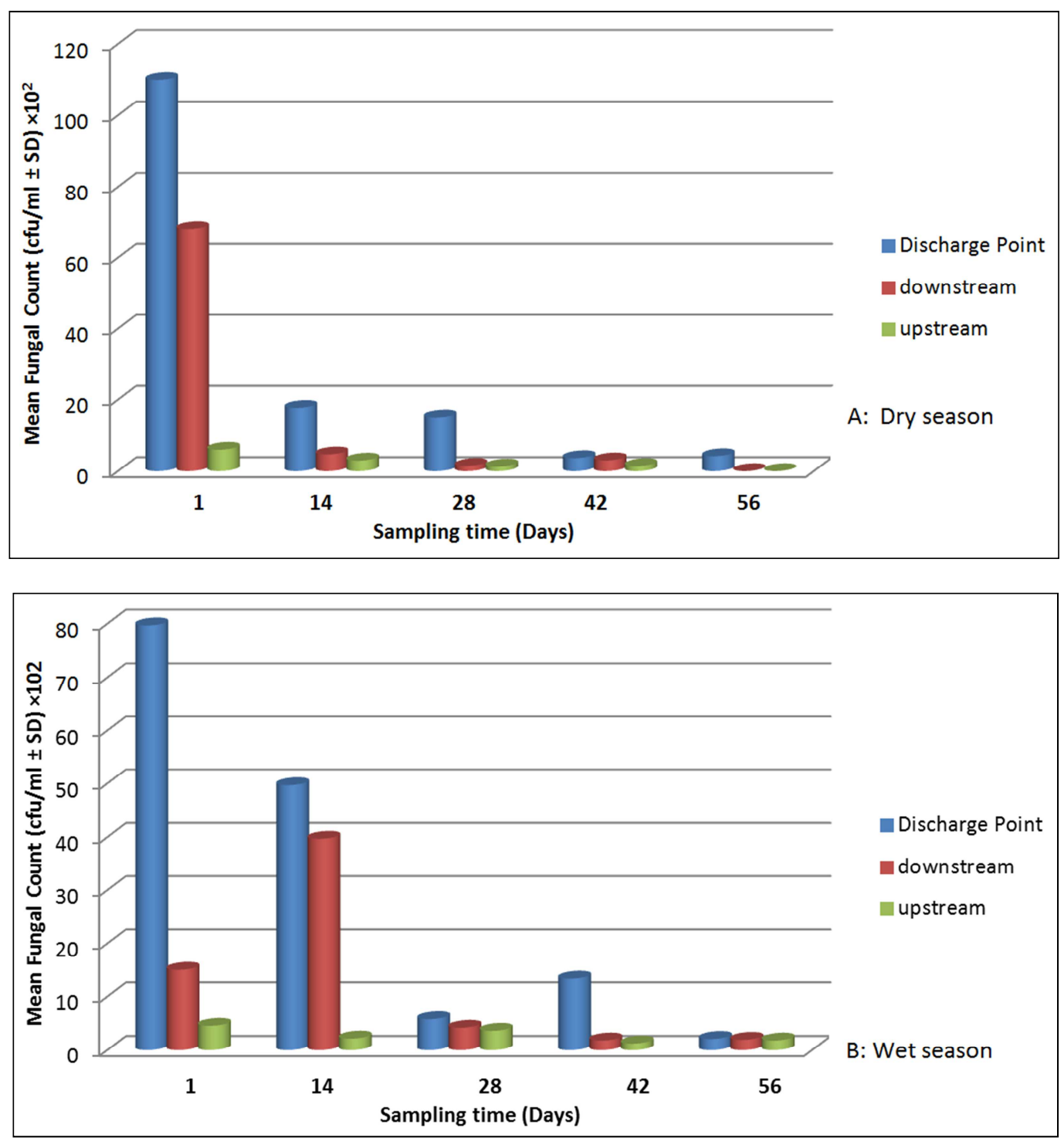

Figures 2. A and B Dry and Wet Seasons Heterotrophic Fungal Count.

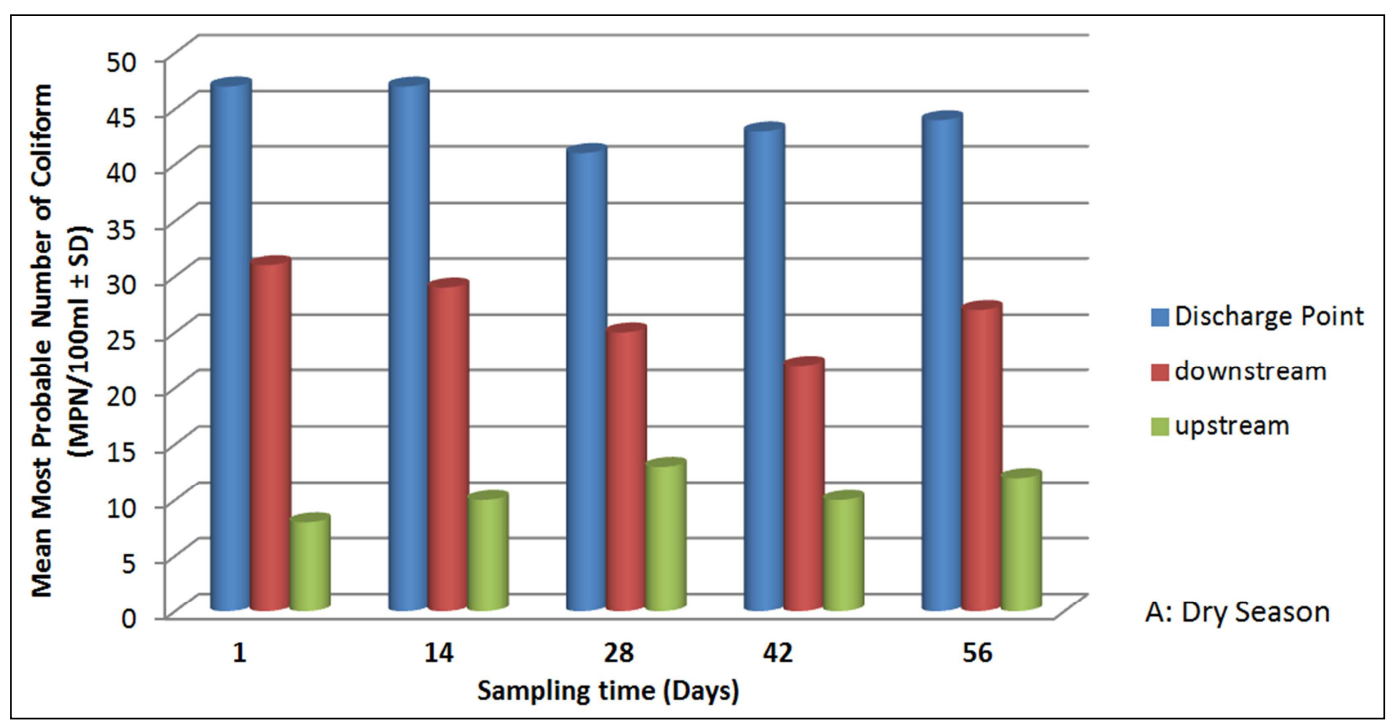




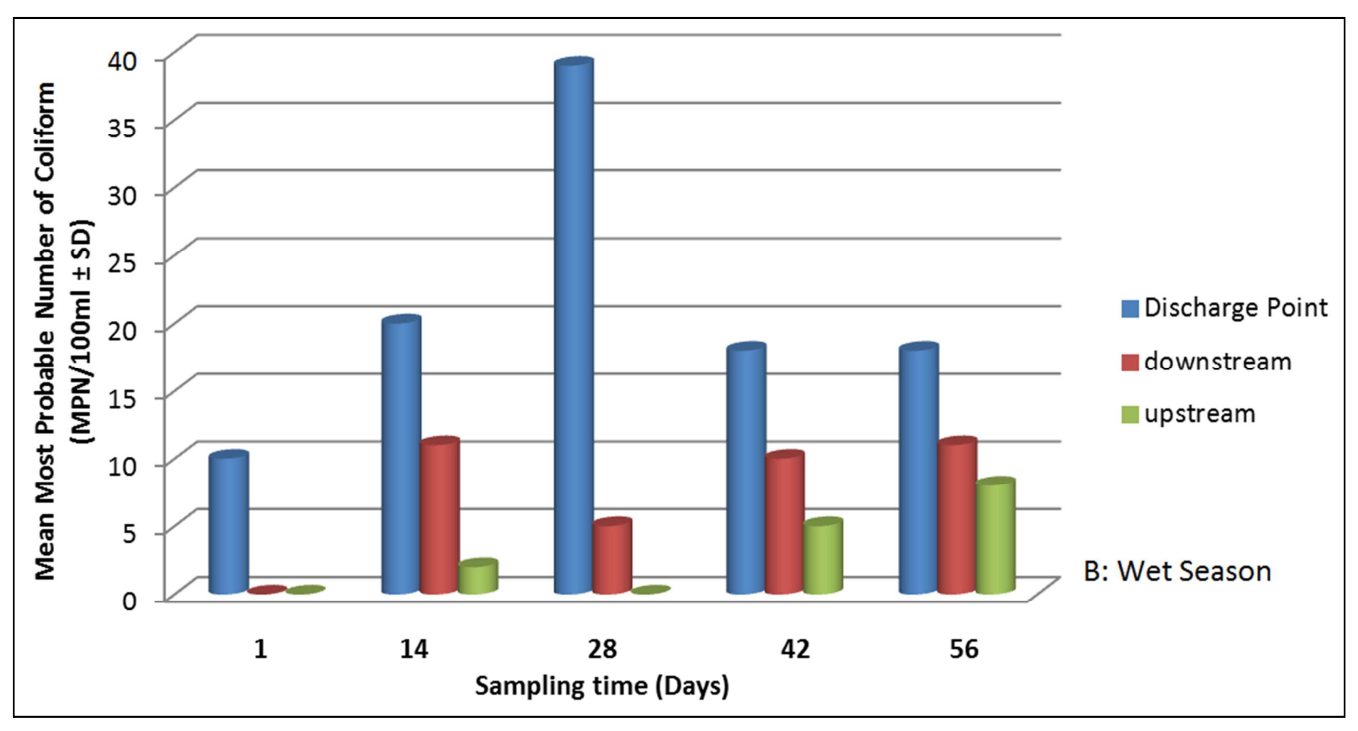

Figures 3. $A$ and B Dry and Wet Seasons Most Probable Number of Coliforms.

Bacteria and fungi were observed in all the samples collected. There was significant difference $(\mathrm{P} \leq 0.05)$ in bacterial counts on Day 1 and 14 in all the sampling points in the two seasons. The dry season total heterotrophic bacterial count ranged from $1.67 \pm 0.12 \times 10^{2}-580.00 \pm$ $20.00 \times 10^{2} \mathrm{cfu} / \mathrm{ml}$. The total heterotrophic bacterial count decreased significantly $(\mathrm{P} \leq 0.05)$ on Day 1 and 14 on both seasons. Dry season total heterotrophic bacterial count also followed a similar trend on Day 28.

Wet season total heterotrophic bacterial count ranged between $1.80 \pm 0.20 \times 10^{2}-60.00 \pm 1.00 \times 10^{2} \mathrm{cfu} / \mathrm{ml}$. There was no significant difference $(\mathrm{P} \leq 0.05)$ in total heterotrophic bacterial count at downstream (DS) and upstream (US) on Day 42 and 56 in the dry season. Also, wet season total heterotrophic bacterial count followed the same pattern on day 28 and 56 except day 42 that shows a significant difference $(\mathrm{P} \leq 0.05)$ and the count decreased along the sampling points.

In most of the analyses, there was significant difference $(\mathrm{P} \leq 0.05)$ in counts between the discharge point (DP) and other sampling points i.e downstream (DS) and upstream (US).

In dry season total heterotrophic fungal count, there was no significant difference $(\mathrm{P} \leq 0.05)$ between the counts on day 14, 28, 42 and 56 at DS and UPS. The dry season total heterotrophic fungal count ranged between $1.30 \pm 0.15 \times 10^{2}$ $110.00 \pm 10.00 \times 10^{2} \mathrm{cfu} / \mathrm{ml}$. Day 28, 42 and 56 of wet season total heterotrophic fungal count also recorded similar results. Day 42 and 56 of dry season total heterotrophic fungal count and Day 56 of wet season recorded no significant difference $(\mathrm{P} \leq 0.05)$ in counts in all the sampling points.

In dry season most probable number of coliforms, there was significant difference $(\mathrm{P} \leq 0.05)$ in the coliform counts in all the sampling points with DP having the highest count. The count decreased significantly $(\mathrm{P} \leq 0.05)$ along the sampling points. The dry season most probable number of coliforms ranged from $8.00 \pm 1.00 \times 10^{2}-47.00 \pm 3.00 \times 10^{2} \mathrm{cfu} / \mathrm{ml}$.

In wet season most probable number of coliforms, there was no significant difference $(\mathrm{P} \leq 0.05)$ in counts on day 1,28 and 56 at DS and US sampling points. But other points had significant difference $(\mathrm{P} \leq 0.05)$ in the coliform counts. The wet season coliform counts ranged $<2.00 \pm 0.00 / 100 \mathrm{ml}-$ $39.00 \pm 3.00 / 100 \mathrm{ml}$ of water sample.

From the foregoing analyses, higher bacterial, fungal and coliform counts were recorded at the point of effluent discharge throughout the sampling periods. The high microbial load recorded at DP during the two seasons could be attributed to high organic matter content resulting from the brewery effluents and human activities such as washing and bathing at the vicinity of DP. It has been reported that high microbial population in an aquatic system is a reflection of the input of microorganisms from extraneous sources and the availability of growth supporting matter [19].

Besides the above, the dry season analyses had the highest microbial load but with low diversity of species when compared to wet season. The high density of microbial population during this season could be attributed to the reduced volume of the river during the period coupled with continuous discharge of effluent by the Brewery. High counts of bacterial load reflected the level of water pollution as it gave an indication of the amount of organic matter present [20].

Low density of microbial load with high diversity of species was observed in the wet season. This could be as a result of the dilution effect of the fast-flowing Ikpoba River, pollution from point and non-point sources and other extraneous sources. The changes in diversity of biological communities as a result of the introduction of wastes in an aquatic ecosystem have inspired several authors to utilize diversity indices as a type of biological indicator of pollution [21]. These indices are mathematical expressions of the relationship between the number of species and the abundance [22]. The research has shown that diversity indices based on practical analysis for biological communities are not directly related to the density of the microbial species (the density of microbial species is directly 
related to the volume of water)

The presence of Escherichia coli and Streptococcus faecalis was an indication of faecal pollution of Ikpoba River. The faeces could be passed into the river by the users either directly through the open sewer along the delivery point or at distances from runoff. The presence of these organisms in the river suggests the unsuitability of the water for drinking. Bacterial isolates during the dry season include; Escherichia coli, Salmonella sp and Vibrio sp. wet season isolates include Escherichia coli, Salmonella spp, Vibrio spp, Staphylococcus aureus and Streptococcus faecalis.

Fungal isolates in the dry season include; Aspergillus niger, Aspergillus fumigatus and Penicillium spp. Isolates during wet season include; Aspergillus niiger, Aspiergillus fumigatus, Penicilium spp. and Rhizopus spp.

\section{Conclusion}

The research has shown that brewery effluent (containing organic and inorganic wastes) is the major culprit responsible for the pollution of Ikpoba River. The high microbial load obtained from the Discharge Point (DP) and Downstream (DS) (100m away from DP) compared to Upstream (US) (100m away from DP) where the effect is less also buttressed this fact. Human activities such as defecation, bathing, washing that take place in the river also contributed to the pollution of Ikpoba River. The high microbial density obtained during the dry season was occasioned by the continuous discharged of effluent into the river by the Brewery coupled with the reduction in the volume and water current thereby making the water more settled for microbial proliferation, pollution more pronounced and the odorous effect more felt. Non-point sources of pollution such as runoff and weathering are also implicated in the pollution of Ikpoba River.

The presence of these isolates (E. coli, Staphylococcus aureus, Streptococcus faecalis and species Salmonella and Vibrio) is a clear signal that the river should not be used for domestic purposes particularly for bathing, cooking, and drinking as it could result in an outbreak of water-borne diseases such as cholera and typhoid fever particularly during the dry season when the concentration of organism in the river is high as a result of reduced volume. Those farming at the bank of the river should avoid excessive use of fertilizer that could drain into the river and enrich the water body resulting in algal growth which could affect its aesthetics and the lives of the aquatic ecosystem that are dependent on the water body for survival. Above all, the Brewery should endeavour to treat their wastewater before discharge into the river to mitigate the pollution effect, protect the natural resource and the ecosystem from extinction.

\section{References}

[1] Newton, D. (2008). Chemistry of the Environment. Checkmark books. ISBN 0-8160-7747-9.
[2] Alao, O., Arojojoye, O., Ogunlaye, O. and Fumiyiwa, A. (2010). Impact assessment of brewery effluent on water quality in Majawa, Ibadan, South Western Nigeria. Researcher 2 (5): $21-28$.

[3] Mombeshera, G., Ajayi, S. O. and Osinbajo, O. (1981). Pollution Studies on Nigeria River: Toxic heavy metals status of surface water in Ibadan city. Environment International 2 (5): 49-55.

[4] Aweleh, M. O. and Soubaneh (2014). Wastewater treatment in chemical industries: the concept and current technologies. Hydrology Current Resources 5: 417-750.

[5] Driessen, W. and Vereijeken, T. (2003). Recent Development in Biological Treatment of Brewery Effluent. The Institute and Guide of Brewery Convention, Livingstone, Zambia. March 2-7; 2003.

[6] Gamper-Rabindran, S. and Finger, S. R. (2013). Does industry self regulation reduce pollution? Responsible care in the chemical. Journal Pollution Science 43:1-30.

[7] Pepper, I. L., Gerba, G. E. and Brusseau, M. L. (2006). "Environmental and Pollution Science" $2^{\text {nd }}$ ed. Academic press, San Diego, CA. Pp. 304-442.

[8] Ekhaise, F. O. and Anyansi, C. C. (2005). Influence of breweries effluent discharge on the microbiological and physico-chemical quality of Ikpoba river, Nigeria. African Journal of Biotechnology 4 (10); 1062-1065.

[9] Tariq, M., Ali, M. and Shah, Z. (2006). Characteristics of industrial effluents and their possible impacts on quality of underground water. Soil and Environmental Science 25 (1): 64-69.

[10] Ipeaiyeda, AR. And Onianwa, PC. (2009). quality of the Olosun river in Ibadan, Nigeria. Chemistry and Ecology 25 (3): 189-204.

[11] Olajumoke, A., Oluwatosin, A., Olumuyiwa, O. and Abimbola, E. (2010). Impact assessment of brewery effluent on water quality on Majawe, Ibadan, South-Western Nigeria. Researcher 2 (5): 21-28.

[12] Bello-Osagie, I. O. and Omoruyi, IM. (2002). Effect of brewery effluent on the bacteriology and physico-chemical properties of Ikpoba river, Edo State, Nigeria. Journal of Applied Technology in Environmental Sanitation 2 (4); 197204.

[13] Barton, N. J. (1992). The Lost Rivers of London; A study of their effects upon London and Londoners, and the effects of London and Londoners on them. $3^{\text {rd }}$ ed. Historical publication Ltd, Berkshire London. Pp. 453-460.

[14] Akpomie, O. O., Buzugbe, H. S. and Eze, P. M. (2014). Effect of brewery effluent on the microbiological quality of Ikpoba river and surrounding borehole water in Benin city, Nigeria. British Microbiology Research Journal 5 (1): 76-82, 2015. ISSN: 2231-0886.

[15] Akubugwu, E. I. and Duru, M. K. C. (2011). Human activities and water quality; a case study of Otaimiri river, Imo state. Global Research Journal of Science 1:48-53.

[16] United States Environmental Protection Agency (USEPA) (2002). Method 1680 Faecal coliforms in biosolids by multiple tube fermentation procedures draft. Document number EPA821-R-02-026. 
[17] Cheesbrough, Monica (2006). District Laboratory Practice in Tropical Africa. University of Cambridge $2^{\text {nd }}$ Edition Update Part 2. Pp. 63-70.

[18] Oyeleke, A. and Manga, S. B. (2008). Essentials of Laboratory Practice, $3^{\text {rd }}$, edition, Minna, Niger State, Nigeria. Tobest Publisher, 2008. Pp. 12-29.

[19] Sayler, G. S., Nelson, J. O., Justice, A. and Colwell, R. R. (2010). Distribution and Significance of faecal indicator organisms in the upper chase Park Bay: Journal of Applied and Industrial Microbiology 30 (4): 625-638.
[20] Anson, A. E. and Ware, G. C. (2012). Survey of Distribution of Bacterial Pollution in the Bristol Channel. Journal of Applied Microbiology 37: 657-661.

[21] Personne, C. G. and De Pauw, N. (1999). Systems of biological indicators for water quality assessment in: Roverabiological Aspects of Freshwater Pollution. Pergamon press. Oxford. Pp. 39-75.

[22] Wilhm, J. L. and Dorris, T. C. (2001). Biological Parameters for water quality criteria. Bioscience 18:477-481. 